\title{
Education for Sustainable Development: A Qualitative Analytical Study on the Impact of the Jordanian Universities' Role in Supporting Innovation among University Students
}

\author{
Dr. Amani Jarrar ${ }^{1}$ \\ ${ }^{1}$ Department of Development Studies, Philadelphia University, Jordan \\ Correspondence: Dr. Amani Jarrar, Department of Development Studies, Philadelphia University, Jordan.
}

Received: December 20, 2020

Accepted: April 14, 2021

Online Published: April 20, 2021

doi:10.5430/ijhe.v10n4p268

URL: https://doi.org/10.5430/ijhe.v10n4p268

\begin{abstract}
This study aimed at exploring and theorizing the role of Jordanian Universities in supporting innovation among university students within the context of education for sustainable development from the point of view of Jordanian University students. For that, the researcher adopted the grounded theory methodology by Strauss and Corbin. The study was conducted at two Jordanian Universities: the University of Jordan and Philadelphia University in the academic year (2019-2020), and the study population consisted of students from the two universities. The researcher chose (300) students from both genders from different faculties and academic years. By applying the grounded theory, the study concluded that the key category that emerged after analyzing the student's responses describing the impact of the Jordanian Universities' role in supporting innovation among university students for educational sustainable development is the emphasis on the need for developing proper University innovation ecosystems in their educational systems. Also, the respondents- through online interviews - have emphasized this concept of proper University innovation ecosystems. The key category of this study found that positive and negative impacts could result from applying or neglecting to apply this concept, which generated behaviors toward the concept, which could be considered as the phenomena in the current research.
\end{abstract}

Keywords: education, sustainable development, Jordanian Universities, innovation

\section{Introduction}

To achieve sustainable development through technological solutions and political systems; we need to change our mindsets and behaviors, which requires a comprehensive evaluation of the quality of education and learning for sustainable development at all levels and in all social systems. The main goal of the education systems for sustainable development is to enable meeting the current and future global challenges constructively and creatively, and in creating more resilient sustainable societies (Rieckmann, 2017).

With its multiple concepts; sustainable development can be summarized in the process that results as an increase of life chances for individuals without a decrease in the life chances of others, or in enabling today's man to have a better life and to achieve better well-being, social justice, and safety while preserving the rights of the future man (Harris, 2000).

The beginning was in the Earth Summit held in Brazil (Rio de Janeiro) in 1992, UNESCO acknowledged the use of science, education, public awareness development, and training for sustainable development, and then UNESCO called for establishing an international committee for dealing with the concept of education in its broadest sense, from pre-school education to higher education through school education (Leal Filho, Manolas \& Pace, 2015).

All international reports and conferences have aimed to ensure education for sustainable development through education that enables learners to acquire the necessary techniques, skills, values, and knowledge to ensure sustainable development, as well as education that includes a lifelong learning perspective, and has its return, whether for humans or societies (Leicht, Heiss \& Byun, 2018).

In September 2015, the Member States of the United Nations formally adopted in New York, during their conference on sustainable development, the 2030 Agenda for Sustainable Development. This plan includes 17 goals, including a new global goal in the field of education (Goal 4 of the Sustainable Development Goals), which is "Ensure inclusive and equitable quality education and promote lifelong learning opportunities for all", combined with seven 
targets and three indicators for implementation. Defining this goal was a result of an intensive consultative process conducted by the Member States, with the participation of civil society, educators, trade unions, bilateral agencies, regional organizations, international organizations, private sector, and research institutions (Frey \& MacNaughton, 2016).

Higher education institutions play an important role in achieving the 2030 Sustainable Development Goals. Higher education institutions are specifically mentioned in the framework of the fourth goal of the Sustainable Development Goals regarding the quality and the inclusiveness of education, but their impact extends to all the goals through teaching and learning processes, research outputs, and initiatives undertaken by students. Higher education institutions contribute to social, environmental, and economic development as being one of the most important incubators for ideas and solutions to global problems (Owens, 2017).

Education in Jordan in general, and higher education in particular, is the path to sustainable development, and the universities' outputs are the inputs of the sustainable development processes; within the framework of the fourth goal of the sustainable development goals, which are related to the quality and the comprehensiveness of education, indicating that its impact extends to include all the sustainable development goals, through the transformation processes that generate knowledge and technologies, and from a teacher-centered educational system to a learner-centered educational system (Elrehail, Emeagwali, Alsaad \& Alzghoul, 2018).

And since innovation stimulates productivity, inclusive economic growth, sustainable development, and contributes to finding solutions to social, economic, and environmental challenges, especially in Jordan; an integrated approach in higher education must be based on innovation, which has diversified its forms and models since the beginning of the economic globalization and the information \& communication revolution in the last century. This is presented in the mission of the Ministry of Higher Education and Scientific Research in Jordan in achieving sustainable development by developing an integrated educational system based on innovation.

\section{Problem Statement}

Universities around the world are considered the generators of knowledge and the centers of the civilized progress of nations, and they are playing an unprecedented role of great importance in terms of innovation (Thorp \& Goldstein, 2013). Innovation is about creating new knowledge or applying old knowledge in new ways. In this context, the Jordanian universities are keeping pace with technical progress in trying to adopt policies that serve the idea of shifting towards innovation by offering advanced programs in the field of education and curricula, as well as developing legislations with the Ministry of Higher Education and Scientific Research, to support innovation at all levels. Therefore, the researcher adopted the qualitative analytical methodology for theorizing the impact of the Jordanian Universities' role in supporting innovation among university students within the context of education for sustainable development by attempting to answer the study question: What is the grounded base theory that governs the Jordanian Universities' role in supporting innovation among university students within the context of education for sustainable development?

\section{Objectives of the Study}

Innovation supports shifting towards the learner-centered educational system. Thus, this study is trying to explore the Jordanian Universities' role in supporting innovation among university students within the context of education for sustainable development from the point of view of the students of the Jordanian Universities. And the study aims at:

- Determining the role that Jordanian universities play in developing and investing in innovation.

- Exploring the direct role of the Jordanian universities in developing the human resource capabilities for achieving the development of innovative students' capabilities.

- Investigating the role of the universities' curricula and non-curricula activities in providing students with knowledge that can develop their innovative capabilities.

\section{Literature Review}

Sustainable development is a comprehensive model for the United Nations, the concept of sustainable development was described in the Brundtland Commission 1987 report as a development that meets the needs of the present without compromising the ability of future generations to meet their own needs; and sustainability is a model of thinking about the future that takes into account environmental, social and economic considerations in the pursuit of development and improvement of the quality of life (Redclift, 2005).

To reorient education towards sustainable development, educational institutions must explore the required knowledge, questions, visions, capabilities, and values that are at the core of sustainable development for each of the 
three elements of sustainability; environment, society, and economy to integrate them into the curriculum. The educational community also needs to decide which of the many issues that are related to sustainability will become part of the curriculum (e.g., climate change, equity, poverty) and rationally, the effort of reorienting education based on the local or national sustainability goals (Rieckmann, 2018).

The pedagogy related to education for sustainable development stimulates students to analyze, think critically and make decisions, and it works on stimulating innovation and imagining the future alternatives, working towards a positive change that helps students develop a sense of social justice and self-efficacy as members of the society. Universities have a leading role in defining the trends through which future generations learn how to address the complexity of sustainable development; universities also prepare highly qualified graduates who can satisfy all the needs of human activities. It also provides opportunities for higher education and lifelong learning (sustainability). It also contributes to the advancement, enrichment, and dissemination of knowledge through research, in addition to providing societies with the specialized expertise needed to help in the field of cultural, social, and economic development (Adomßent, Fischer, Godemann, Herzig, Otte,

Rieckmann \& Timm, 2014).

The university is the educational institution with its developmental goal; it can understand and respond to the interrelationships between various systems and all segments of the society by determining options and adjusting paths under the supervision of intellectual and academic energies to provide strategic services to restore the balance between needs and goals, as part of the state's policy aimed at developing and directing youth towards the future. Universities also have a role in supporting innovation, which is a fundamental role assigned to universities through curricula and training workshops that support creative thinking and innovation, as well as through entrepreneurship incubators that help transform these ideas into products and service projects (Sharples, Roock, Ferguson, Gaved, Herodotou, Koh, \& Wong, 2016).

\section{Methods and Procedures}

\subsection{Study Methodology}

For subjective interpretation of the content of the interviews text data as a research method; the qualitative analysis can be referred to as a process of identifying and then coding themes into patterns through a systematic classification (Hsieh \& Shannon, 2005, p. 1278). Besides that, it is "a method for describing the meaning of qualitative material systematically". Therefore, the researcher has adopted the grounded theory methodology by Strauss and Corbin (1990, 1998).

\subsection{Study Population and Sample}

The study population consisted of all the students in the two Jordanian universities: the University of Jordan and Philadelphia University in the academic year (2019-2020); and the researcher conducted the study on a sample of (300) students; as a representative sample size with different faculties, gender, and academic year.

\subsection{Characteristics of the Study Sample}

Data in table 1 show the distributions of the study sample by faculty, gender, and academic year.

Table 1. Study sample characteristics

\begin{tabular}{llcc}
\hline & Variables & Frequencies & Percentages \\
\hline \multirow{2}{*}{ Gender } & Male & 136 & $45.6 \%$ \\
& Female & 164 & $54.4 \%$ \\
Faculty & Scientific & 112 & $37.4 \%$ \\
& Humanitarian & 188 & $62.6 \%$ \\
\multirow{3}{*}{ Academic year level } & 61 & $20.4 \%$ \\
& First-year & 89 & $29.6 \%$ \\
& Second-year & 70 & $23.3 \%$ \\
& Third-year & 80 & $26.7 \%$ \\
\hline
\end{tabular}

\subsection{Interview Questions}

All the interview questions were based on an open-ended approach, and the questions are:

1. How would you describe the idea that the teaching methods in the university support the concept of innovation to achieve sustainable development? 
2. How would you describe the idea that the curricula taught at the university support the concept of innovation to achieve sustainable development?

3. How would you describe the idea that the non-curricula activities in the university support the concept of innovation to achieve sustainable development?

4. In what way or ways do you think that the university supports the concept of scientific research among students to encourage them to innovate?

5. As a student, how would you describe your constructive contributions to initiate ideas that could support the concept of innovation to achieve sustainable development of the educational system?

6. What could be the positive sides of the university that do support the concept of innovation to achieve sustainable development?

7. What could be the negative sides of the university that do not support the concept of innovation to achieve sustainable development?

\subsection{The Coding Process}

By using grounded theory procedures; data were collected suggesting that for a standard grounded theory research; 20 to 30 interviews should be executed, which will cover the categories that emerge during analysis as a sum. The accumulated data in the four phases will differ upon the purpose and the strategies of the data collection. By using (NVivo 11), the data analysis of this study was completed to face trustworthiness, rigorousness, and quality. The data collection four-stage strategy is summarized in Table 2.

Table 2. Data Collection Four Phases

\begin{tabular}{llll}
\hline Phase & \multicolumn{1}{c}{ Coding } & \multicolumn{1}{c}{ Purpose } & \multicolumn{1}{c}{ Respondents } \\
\hline One & Open & For advanced analysis; Categorizing codes & $\begin{array}{l}60 \text { individuals, and 40 in } \\
\text { Focus groups }\end{array}$ \\
Two & Axial & Specifying and connecting codes to generate themes & $\begin{array}{l}60 \text { individuals, and } 40 \text { in } \\
\text { Focus groups }\end{array}$ \\
Three & Selective & $\begin{array}{l}\text { Generating the paradigm model } \\
50 \text { in Focus groups }\end{array}$ \\
Four & Selective & $\begin{array}{l}\text { Until saturated; testing, certifying, and explaining the } \\
\text { paradigm model }\end{array}$ & 50 in Focus groups \\
\hline
\end{tabular}

5.6 Study Analysis

The obtained 29 preliminary codes from the interview sessions are shown in table 3 ; as each code is representing a significant topic of discussion related to the impact of the Jordanian Universities' role in supporting innovation among university students. Therefore, the researcher concluded that the codes were saturated by both the focus groups and individual interviews that were necessary to understand the phenomenon of the impact of the Jordanian Universities' role in supporting innovation among university students after similar codes emerging during the interviews.

Table 3. Initial Categories and Codes in Phase one and two

\begin{tabular}{|c|c|}
\hline Categories & Codes \\
\hline \multirow{8}{*}{ Knowledge background } & University innovation ecosystems \\
\hline & Innovation knowledge exchanges \\
\hline & $\begin{array}{l}\text { Understanding the inner dynamics of knowledge } \\
\text { economy }\end{array}$ \\
\hline & The need for new organizational processes \\
\hline & $\begin{array}{l}\text { Universities' ability to build and improve their research } \\
\text { methodologies }\end{array}$ \\
\hline & Knowledge-based capital \\
\hline & $\begin{array}{l}\text { Universities' ability to build and improve their teaching } \\
\text { methods }\end{array}$ \\
\hline & $\begin{array}{l}\text { Interactions between } \\
\text { economic actors }\end{array}$ \\
\hline & Legislations supporting the innovation ecosystems \\
\hline Interactions & $10 \begin{array}{l}\text { Linking education to the goals of sustainable } \\
\text { development }\end{array}$ \\
\hline
\end{tabular}




\begin{tabular}{lll}
\hline & 11 & Innovation linked to developing supportive curricula \\
12 & Teaching method development \\
13 & Scientific research is the cornerstone \\
14 & Encouraging creative thinking \\
15 & Networking with companies \\
16 & Economic growth \\
& 17 & Long-life Sustainable education development \\
& 18 & Advanced social ecosystems \\
Phenomenon: Positive sides & 19 & Social justice \\
& 20 & Generating knowledge \\
& 21 & Unbalanced Sustainable development \\
& 22 & Social injustice \\
Phenomenon: Negative sides & 23 & Poor social ecosystems \\
& 24 & Weak economy \\
25 & Traditional education \\
& 26 & Failure to achieve any success in the sustainable \\
& 27 & Underdeveloped societies \\
Consequences & 28 & Economy collapse \\
29 & The collapse of the educational system \\
\hline
\end{tabular}

\section{Results and Discussion}

\subsection{Study Paradigm Model}

By utilizing NVivo 11 the paradigm model in figure 1 is generated as a result of codes and themes linked together. These concepts' relationships are established based on the validation process in the third and the fourth phases of the selective data analysis rigorously.

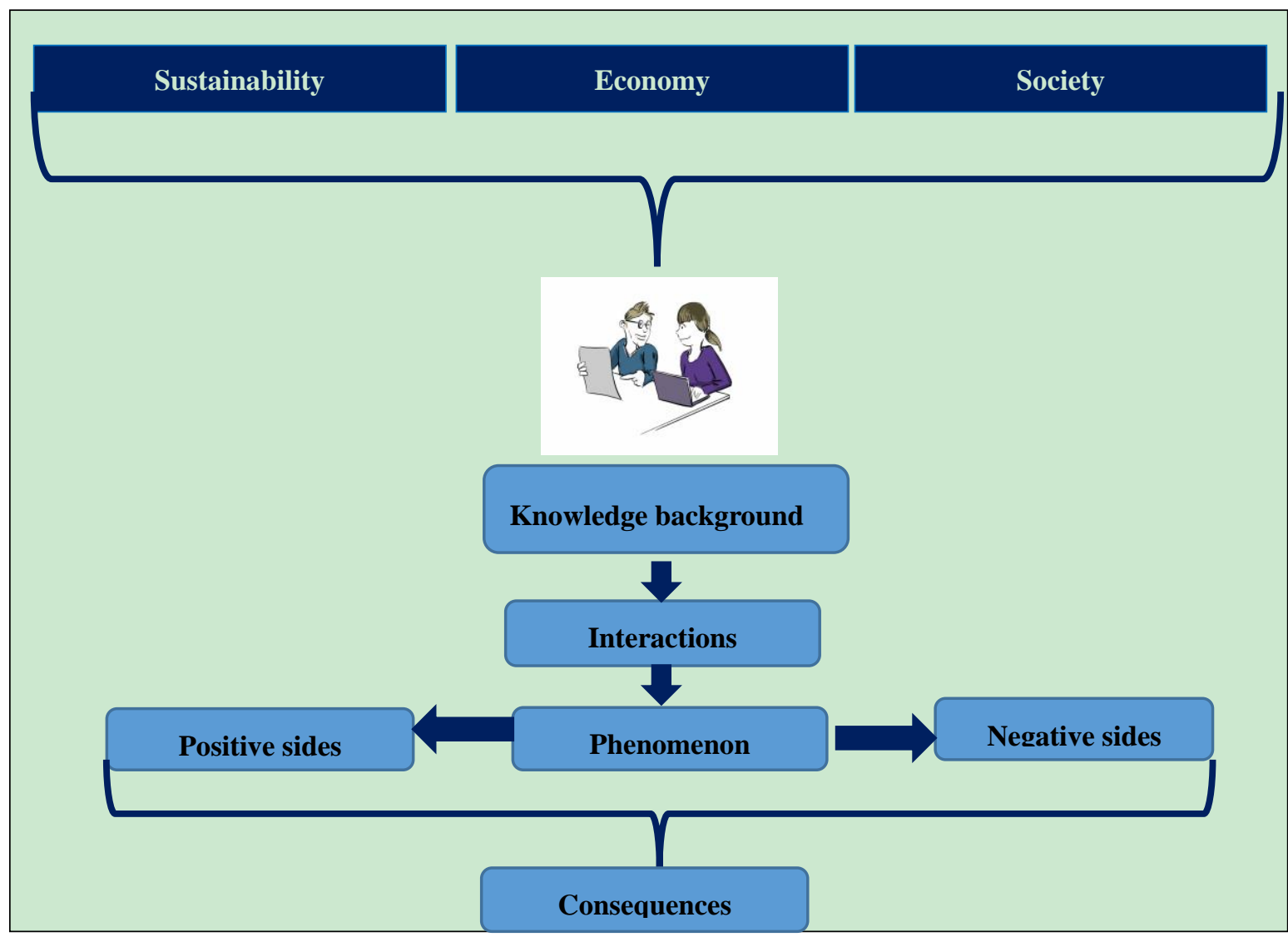

Figure 1. The Paradigm Model 


\subsection{Codes into Themes}

Percentages of codes into themes frequencies of the study sample answers upon the study sample characteristics as distributed by gender (males and females) and faculty stream (scientific and humanitarian), and table 4 shows these percentages.

Table 4. Percentages of codes into themes frequencies of the study sample answers upon the study sample characteristics

\begin{tabular}{|c|c|c|c|c|}
\hline \multirow{3}{*}{$\begin{array}{c}\text { Codes into themes } \\
\text { Knowledge background }\end{array}$} & \multicolumn{4}{|c|}{ Percentages } \\
\hline & \multicolumn{2}{|c|}{ Gender } & \multicolumn{2}{|c|}{ Faculty } \\
\hline & Male & Female & Scientific & Humanitarian \\
\hline University innovation ecosystems & $41 \%$ & $43 \%$ & $45 \%$ & $41 \%$ \\
\hline Innovation knowledge exchanges & $29 \%$ & $30 \%$ & $44 \%$ & $49 \%$ \\
\hline $\begin{array}{l}\text { Understanding the inner dynamics of the knowledge } \\
\text { economy }\end{array}$ & $33 \%$ & $27 \%$ & $38 \%$ & $41 \%$ \\
\hline The need for new organizational processes & $18 \%$ & $30 \%$ & $44 \%$ & $43 \%$ \\
\hline $\begin{array}{l}\text { Universities' ability to build and improve their research } \\
\text { methodologies }\end{array}$ & $27 \%$ & $29 \%$ & $51 \%$ & $40 \%$ \\
\hline Knowledge-based capital & $32 \%$ & $31 \%$ & $32 \%$ & $39 \%$ \\
\hline $\begin{array}{l}\text { Universities' ability to build and improve their teaching } \\
\text { methods }\end{array}$ & $25 \%$ & $26 \%$ & $45 \%$ & $41 \%$ \\
\hline $\begin{array}{l}\text { Interactions between Universities' students and } \\
\text { economic actors }\end{array}$ & $28 \%$ & $37 \%$ & $31 \%$ & $28 \%$ \\
\hline \multirow{3}{*}{$\begin{array}{l}\text { Codes into themes } \\
\text { Interactions }\end{array}$} & \multicolumn{4}{|c|}{ Percentages } \\
\hline & \multicolumn{2}{|c|}{ Gender } & \multicolumn{2}{|c|}{ Faculty } \\
\hline & Male & Female & Scientific & Humanitarian \\
\hline Legislations supporting the innovation ecosystems & $51 \%$ & $56 \%$ & $66 \%$ & $52 \%$ \\
\hline $\begin{array}{l}\text { Linking education to the goals of sustainable } \\
\text { development }\end{array}$ & $49 \%$ & $55 \%$ & $48 \%$ & $41 \%$ \\
\hline Innovation linked to developing supportive curricula & $34 \%$ & $33 \%$ & $41 \%$ & $39 \%$ \\
\hline Teaching method development & $53 \%$ & $54 \%$ & $49 \%$ & $43 \%$ \\
\hline Scientific research is the cornerstone & $59 \%$ & $61 \%$ & $74 \%$ & $55 \%$ \\
\hline Encouraging creative thinking & $41 \%$ & $40 \%$ & $48 \%$ & $39 \%$ \\
\hline Networking with companies & $33 \%$ & $31 \%$ & $40 \%$ & $32 \%$ \\
\hline & \multicolumn{4}{|c|}{ Percentages } \\
\hline Chemes into themes & \multicolumn{2}{|c|}{ Gender } & \multicolumn{2}{|c|}{ Faculty } \\
\hline Phenomenon: Positive sides & Male & Female & Scientific & Humanitarian \\
\hline Economic growth & $62 \%$ & $71 \%$ & $59 \%$ & $64 \%$ \\
\hline Long-life Sustainable education development & $53 \%$ & $52 \%$ & $49 \%$ & $50 \%$ \\
\hline Advanced social ecosystems & $44 \%$ & $45 \%$ & $50 \%$ & $48 \%$ \\
\hline Social justice & $67 \%$ & $68 \%$ & $57 \%$ & $60 \%$ \\
\hline Generating knowledge & $54 \%$ & $55 \%$ & $63 \%$ & $51 \%$ \\
\hline & \multicolumn{4}{|c|}{ Percentages } \\
\hline Phenemenon. Nequative sidec & \multicolumn{2}{|c|}{ Gender } & \multicolumn{2}{|c|}{ Faculty } \\
\hline & Male & Female & Scientific & Humanitarian \\
\hline
\end{tabular}


Unbalanced Sustainable development

Social injustice

Poor social ecosystems

Weak economy

Traditional education

\section{Consequences}

Failure to achieve any success in the sustainable development goals

Underdeveloped societies

Economy collapse

The collapse of the educational system

$\begin{array}{llr}36 \% & 39 \% & 41 \% \\ 54 \% & 56 \% & 50 \% \\ 44 \% & 48 \% & 41 \% \\ 59 \% & 62 \% & 54 \% \\ 45 \% & 38 \% & 46 \% \\ & & \text { Percentages }\end{array}$

Gender

Male Female Scientific Humanitarian

$\begin{array}{llll}44 \% & 51 \% & 50 \% & 47 \% \\ 55 \% & 61 \% & 49 \% & 48 \% \\ 37 \% & 43 \% & 44 \% & 39 \% \\ 54 \% & 61 \% & 52 \% & 55 \%\end{array}$

6.3 Intersections with Sustainable Development

Based on the paradigm model above; data showed that there are many intersections between sustainable development and the ideas presented in the study sample responses, and these intersections can be divided into clusters; with each cluster representing the networking connections of the ideas generated by the codes turned into themes in the four phases of the data collection.

6.3.1 Cluster One: Education for Sustainable Development with Economics

Data in figure 2 show the cluster interrelationships between education for sustainable development and the economy.

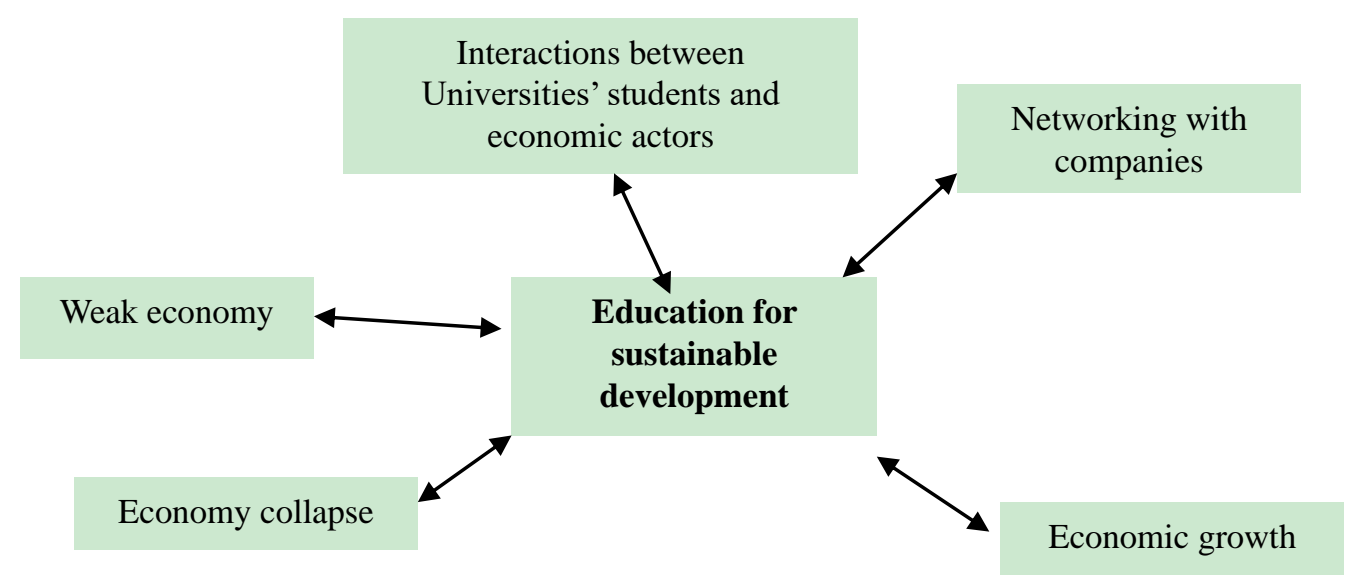

Figure 2. Cluster interrelationships between education for sustainable development and economy

Data in figure 3 also show that the linking percentages between education for sustainable development and economy.

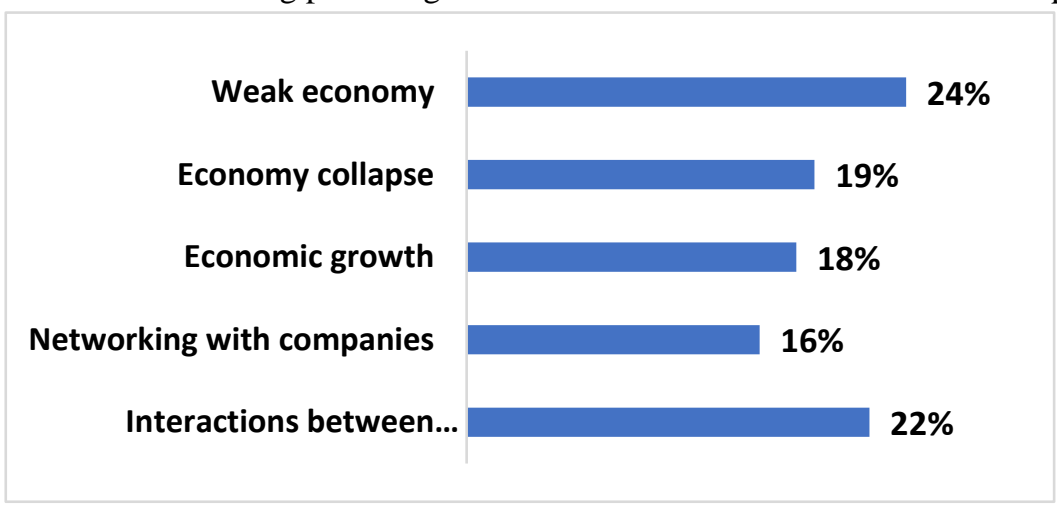

Figure 3. Cluster linking percentages between education for sustainable development and economy 
The highest percentage is for the (Weak economy) concept; reflecting that if universities and higher education institutions do not link the educational processes with the fundamentals of the national economy and its objectives for individuals, groups and the state as a whole, then this will lead to the weakness of the country's economy.

\subsubsection{Cluster two: Education for Sustainable Development with Knowledge}

Data in figure 4 show the cluster interrelationships between education for sustainable development and knowledge.

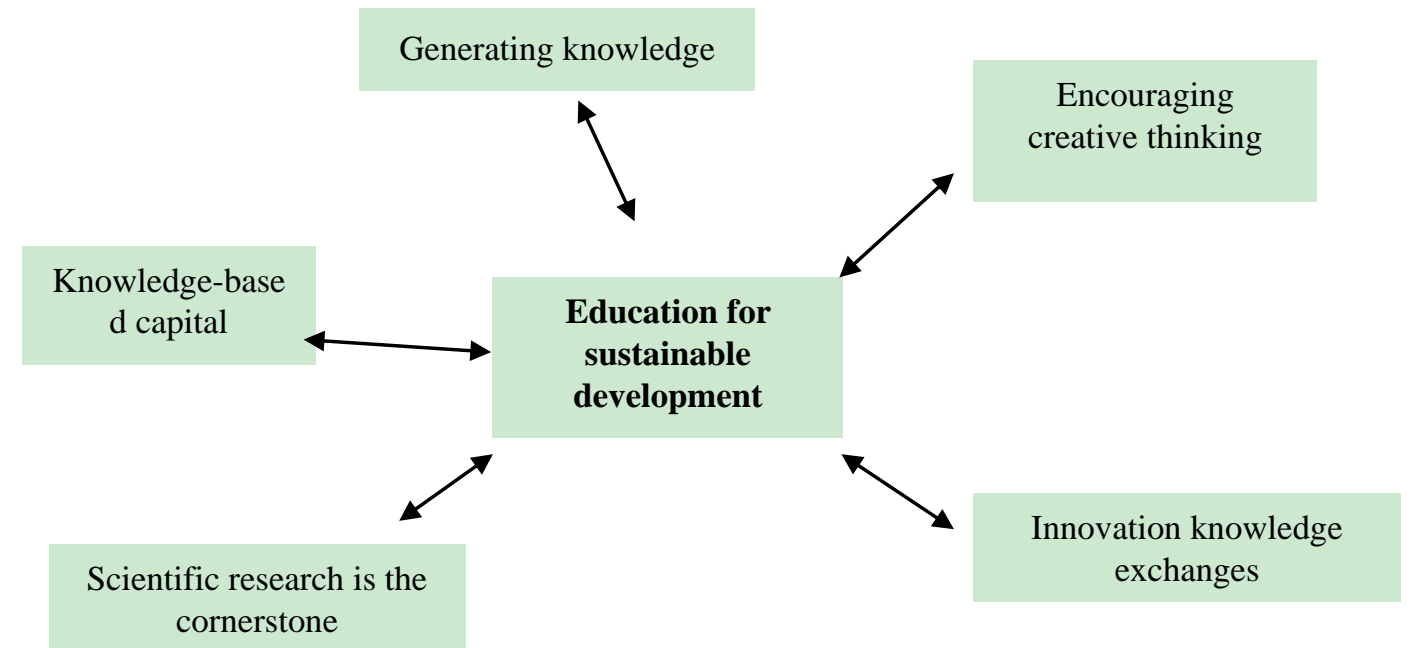

Figure 4. Cluster interrelationships between education for sustainable development and knowledge

Data in figure 5 also shows the linking percentages between education for sustainable development and knowledge.

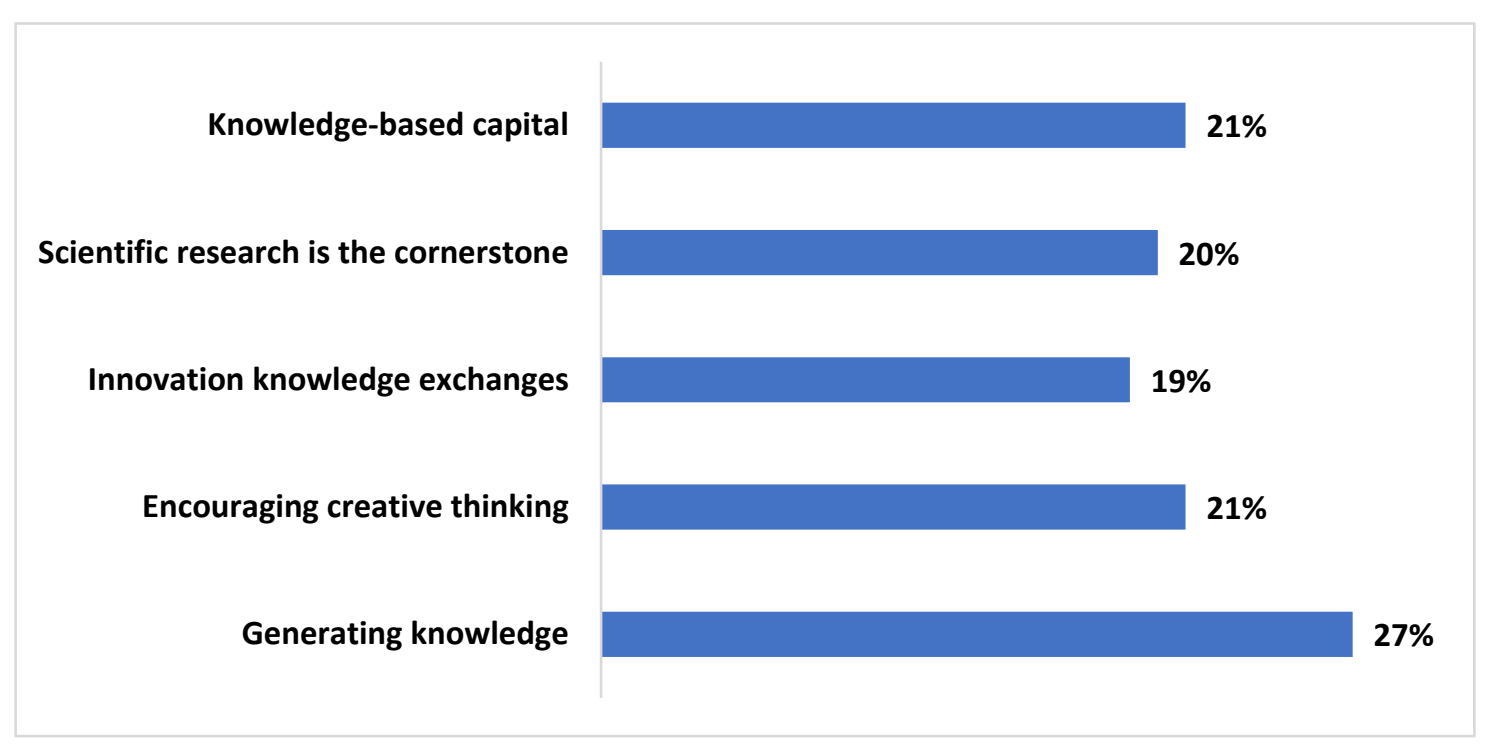

Figure 5. Cluster linking percentages between education for sustainable development and knowledge

The highest percentage is for the (Generating knowledge) concept; reflecting that if universities and higher education institutions do link the educational process with knowledge, that will generate the appropriate knowledge for sustainability.

\subsubsection{Cluster Three: Education for Sustainable Development with Society}

Data in figure 5 show the cluster interrelationships between education for sustainable development and society. 


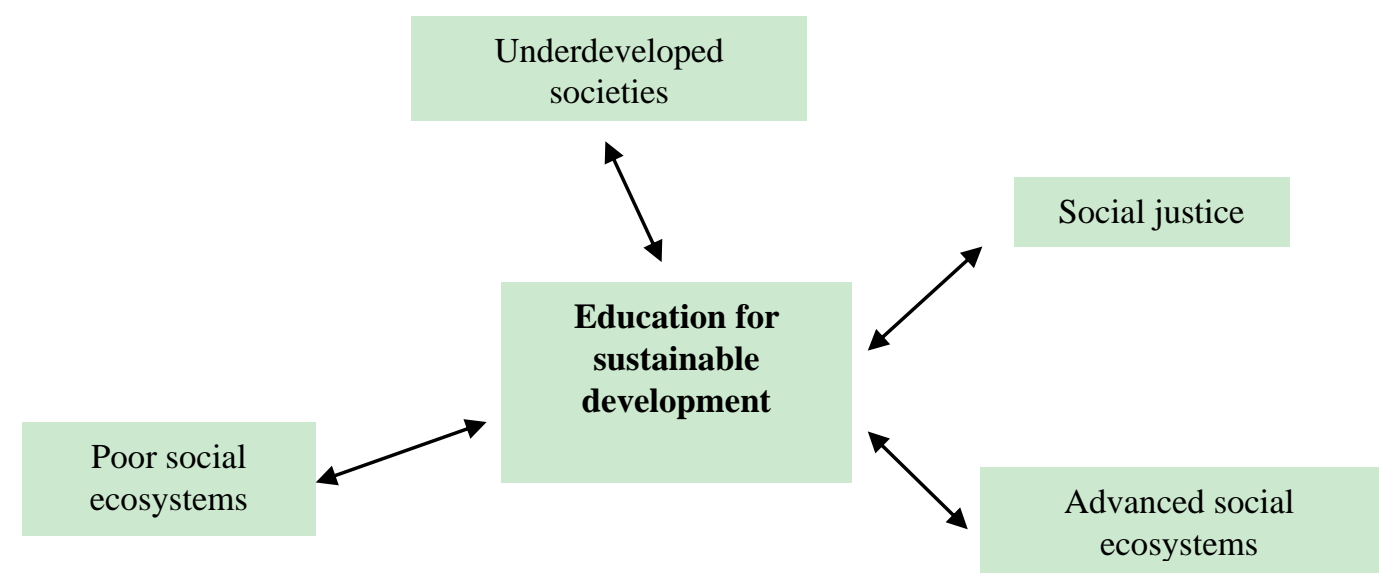

Figure 6. Cluster interrelationships between education for sustainable development and society

Data in figure 7 also show that the linking percentages between education for sustainable development and society.

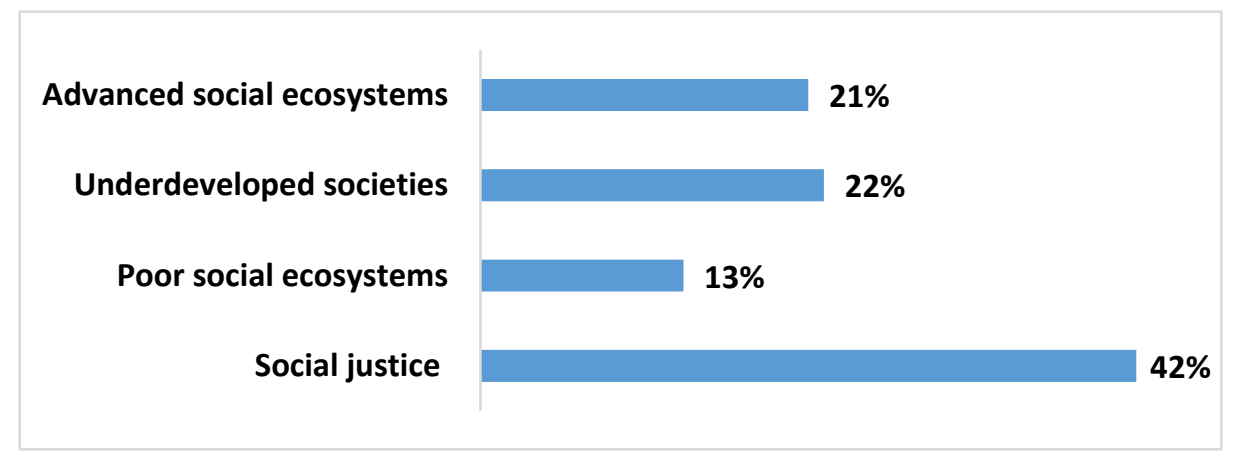

Figure 7. Cluster linking percentages between education for sustainable development and society

The highest percentage is for the (Social justice) concept; reflecting that if universities and higher education institutions do link the educational process with the social dimensions and their goals will lead to social justice.

6.3.4 Cluster Four: Education for Sustainable Development with Innovation

Data in figure 8 show the cluster interrelationships between education for sustainable development and innovation.

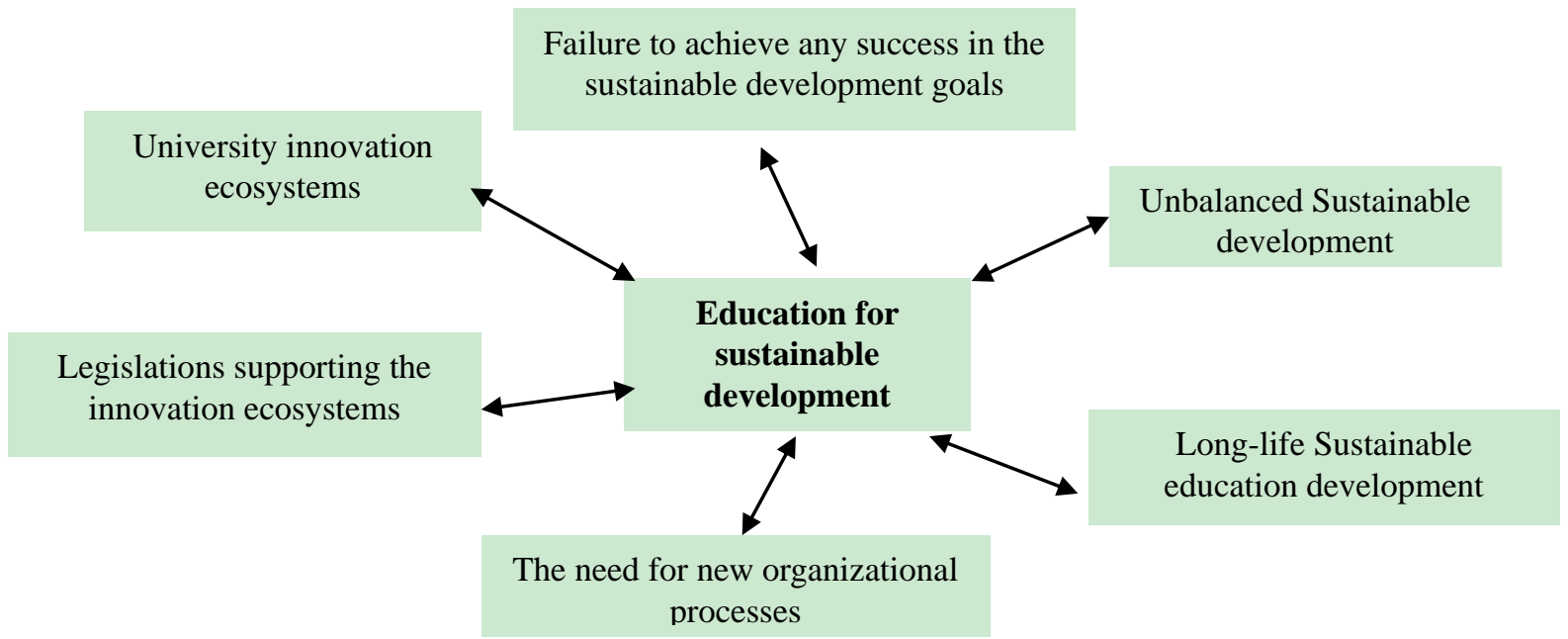

Figure 8. Cluster interrelationships between education for sustainable development and innovation Data in table 5 show the opposites if (if not) applied. 
Table 5. Opposites if (if not) applied

\begin{tabular}{|c|c|}
\hline Theme & Opposites if applied \\
\hline University innovation ecosystems & A clear vision of innovation ecosystems at universities \\
\hline $\begin{array}{l}\text { Legislations supporting the innovation } \\
\text { ecosystems }\end{array}$ & Easier implementation of innovation ecosystems at universities \\
\hline $\begin{array}{l}\text { As consequences of not adopting a clear } \\
\text { innovation ecosystem }\end{array}$ & $\begin{array}{l}\text { - Unbalanced Sustainable development } \\
\text { - } \quad \text { Failure to achieve any success in the sustainable development } \\
\text { goals }\end{array}$ \\
\hline
\end{tabular}

As a direct result of adopting a clear innovation ecosystem

Long-life Sustainable education development

For adopting a clear innovation ecosystem

There is a need for new organizational processes

Data in table 5 show that for adopting a clear innovation ecosystem; the appropriate legislations supporting the innovation ecosystems must be adopted first, besides the need of adopting new organizational processes.

6.3.5 Cluster Five: Education for Sustainable Development with the Educational System

Data in figure 9 show the cluster interrelationships between education for sustainable development and the educational system.

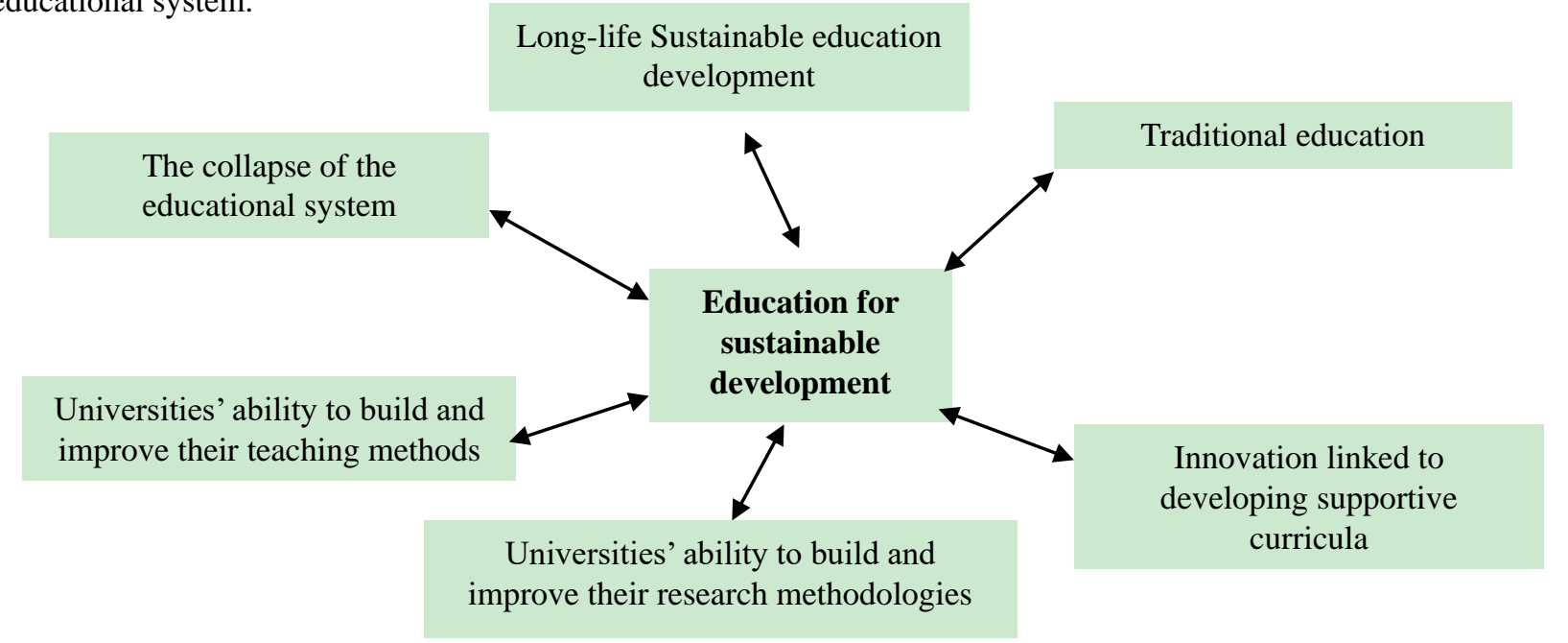

Figure 9. Cluster interrelationships between education for sustainable development and the educational system

Data in table 6 show the opposites if (if not) applied.

Table 6. Opposites if (if not) applied

\begin{tabular}{ll}
\hline Theme & Opposites if applied \\
\hline Universities' ability to build and improve
\end{tabular}

Universities' ability to build and improve

their research methodologies

Universities' ability to build and improve

Long-life Sustainable education development

their teaching methods

Innovation linked to developing supportive curricula

Long-life Sustainable education development

Traditional education

The collapse of the educational system 
Data in table 6 show that in the case of that universities improved their ability to build and improve their research methodologies, their teaching methods, and linking innovation with developed supportive curricula; this will lead to long-life sustainable education development.

\section{Conclusions}

By utilizing NVivo 11, the paradigm model in figure 1 is generated as a result of codes and themes linked together. These concepts' relationships are established based on the validation process in the third and fourth phases of the rigorously selective data analysis.

This model includes knowledge background and interactions of the impact of the Jordanian Universities' role in supporting innovation among university students for an educational sustainable development, positive and negative sides, and the consequences according to respondents' answers. The effectiveness of the grounded theory through the methodology of the qualitative research, by constructing ideas which are the data grounded under investigation, and the way how the theoretical concepts are associated to existing. The research findings have indicated that the respondents' expressions have authenticated the presented theoretical categories, and investigating the flexibility of the research, then by promoting respondents to express their words upon their insights; forming unique outcomes. Thus, the researcher found that the credible and validated hypothesis is to be put forward as the confirmed grounded theory hypothesis. However, it was the phrase of proper "University innovation ecosystems" as a probable key category that led to the validation of the suggested hypothesis. Therefore, the key category is the respondents describing the impact of the Jordanian Universities' role in supporting innovation among university students for an educational sustainable development desired to get proper "University innovation ecosystems" over their educational systems. Progressively, the respondents accomplished their use of online communication have established this concept of proper "University innovation ecosystems". This key category has thus generated behaviors that caused negative and positive impacts on the students, which could be regarded as the phenomena in the current research.

\section{References}

Adomßent, M., Fischer, D., Godemann, J., Herzig, C., Otte, I., Rieckmann, M., \& Timm, J. (2014). Emerging areas in research on higher education for sustainable development-management education, sustainable consumption and perspectives from Central and Eastern Europe. Journal of cleaner production,62, 1-7. https://doi.org/10.1016/j.jclepro.2013.09.045

Corbin, J., \& Strauss, A. (2008). Basics of qualitative research: Techniques and procedures for developing grounded theory. https://doi.org/10.4135/9781452230153

Elrehail, H., Emeagwali, O. L., Alsaad, A., \& Alzghoul, A. (2018). The impact of transformational and authentic leadership on innovation in higher education: the contingent role of knowledge sharing. Telematics and Informatics, 35(1), 55-67. https://doi.org/10.1016/j.tele.2017.09.018

Frey, D. F., \& MacNaughton, G. (2016). A human rights lens on full employment and decent work in the 2030 $\begin{array}{llll}\text { sustainable development } \quad \text { agenda. SAGE } & & \text { Open, 6(2), }\end{array}$ https://doi.org/10.1177/2158244016649580

Harris, J. M. (2000). Basic principles of sustainable development. Dimensions of Sustainable Development, 21-41. https://books.google.jo/books?hl=ar\&lr=\&id=lyBlCwAAQBAJ\&oi=fnd\&pg=PA21\&dq=Harris,+J.+M.+(2000) .+Basic+principles+of +sustainable+development.+Dimensions+\&ots=k3rAhrfATb\&sig=ldKG6mk81Cc5ZigZtj Pn4019CVM\&redir_esc=y\#v=onepage\&q\&f=false.

Hsieh, H., \& Shannon, S. (2005). Three approaches to qualitative content analysis. Qualitative health research, 15(9), 1277-1288. https://doi.org/10.1177/1049732305276687

Leal Filho, W., Manolas, E., \& Pace, P. (2015). The future we want: Key issues on sustainable development in higher education after Rio and the UN decade of education for sustainable development. International Journal of Sustainability in Higher Education. https://doi.org/10.1108/IJSHE-03-2014-0036

Leicht, A., Heiss, J., \& Byun, W. J. (2018). Issues and trends in education for sustainable development (Vol. 5). UNESCO Publishing.

Owens, T. L. (2017). Higher education in the sustainable development goals framework. European Journal of Education, 52(4), 414-420. https://doi.org/10.1111/ejed.12237

Redclift, M. (2005). Sustainable development (1987-2005): an oxymoron comes of age. Sustainable development, 13(4), 212-227. https://doi.org/10.1002/sd.281 
Rieckmann, M. (2017). Education for sustainable development goals: Learning objectives. Unesco Publishing. https://books.google.jo/books?hl=ar\&lr=\&id=Fku8DgAAQBAJ\&oi=fnd\&pg=PP4\&dq=Rieckmann,+M.+(2017 ).+Education+for+sustainable+development+goals:+Learning+objectives\&ots=ZNGAll6ace\&sig=GnZxPAUp9 rAyh3UhFl2QZxiQ17o\&redir_esc=y\#v=onepage\&q=Rieckmann\%2C\%20M.\%20(2017).\%20Education\%20for $\% 20$ sustainable\%20development\%20goals\%3A\%20Learning\%20objectives\&f=false.

Rieckmann, M. (2018). Learning to transform the world: key competencies in Education for Sustainable Development. Issues and trends in education for sustainable development, 39.

Sharples, M., de Roock, R., Ferguson, R., Gaved, M., Herodotou, C., Koh, E., \& Wong, L. H. (2016). Innovating pedagogy 2016: Open University innovation report 5. Institute of Educational Technology. The Open University.

Thorp, H., \& Goldstein, B. (2013). Engines of innovation: The entrepreneurial university in the twenty-first century. UNC Press Books.

\section{Copyrights}

Copyright for this article is retained by the author(s), with first publication rights granted to the journal.

This is an open-access article distributed under the terms and conditions of the Creative Commons Attribution license (http://creativecommons.org/licenses/by/4.0/). 